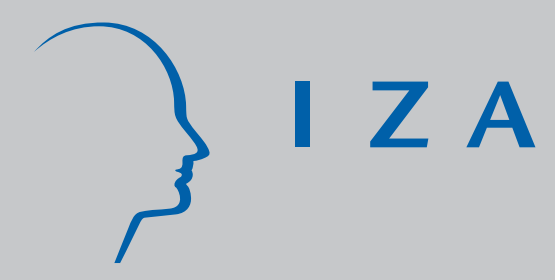

IZA DP No. 3055

The Wage Impact of Trade Unions in the UK Public and Private Sectors

David G. Blanchflower

Alex Bryson

September 2007 


\title{
The Wage Impact of Trade Unions in the UK Public and Private Sectors
}

\author{
David G. Blanchflower \\ Dartmouth College, University of Stirling, \\ Bank of England, NBER, CESifo and IZA \\ Alex Bryson \\ Policy Studies Institute \\ and Centre for Economic Performance
}
Discussion Paper No. 3055
September 2007

\author{
IZA \\ P.O. Box 7240 \\ 53072 Bonn \\ Germany \\ Phone: +49-228-3894-0 \\ Fax: +49-228-3894-180 \\ E-mail: iza@iza.org
}

\begin{abstract}
Any opinions expressed here are those of the author(s) and not those of the institute. Research disseminated by IZA may include views on policy, but the institute itself takes no institutional policy positions.

The Institute for the Study of Labor (IZA) in Bonn is a local and virtual international research center and a place of communication between science, politics and business. IZA is an independent nonprofit company supported by Deutsche Post World Net. The center is associated with the University of Bonn and offers a stimulating research environment through its research networks, research support, and visitors and doctoral programs. IZA engages in (i) original and internationally competitive research in all fields of labor economics, (ii) development of policy concepts, and (iii) dissemination of research results and concepts to the interested public.
\end{abstract}

IZA Discussion Papers often represent preliminary work and are circulated to encourage discussion. Citation of such a paper should account for its provisional character. A revised version may be available directly from the author. 
IZA Discussion Paper No. 3055

September 2007

\section{ABSTRACT \\ The Wage Impact of Trade Unions In the UK Public and Private Sectors ${ }^{*}$}

This paper draws attention to an increase in the size of the union membership wage premium in the UK public sector relative to the private sector. We find the public sector membership wage premium is approximately double that in the private sector controlling for a full range of individual, job and workplace characteristics. Using data from the Labour Force Surveys of 1993-2006 the gap between the membership premium in the public and private sectors closes with the addition of three digit occupational controls, although significant wage premia remain in both sectors. However, using data from the Workplace Employment Relations Survey of 2004, the public sector union membership wage premium remains roughly twice the size of the private sector membership premium having accounted for workplace fixed effects, workers' occupations, their job characteristics, qualifications and worker demographics. Furthermore, the membership wage premium among workers covered by collective bargaining is only apparent in the public sector.

JEL Classification: J31

Keywords: trade unions, wage differentials, public and private sectors

Corresponding author:

David G. Blanchflower

Department of Economics

6106 Rockefeller Hall

Dartmouth College

Hanover, NH 03755-3514

USA

E-mail: blanchflower@dartmouth.edu

\footnotetext{
* We thank Richard Freeman, Steve Machin, David Metcalf, John Pencavel and Andrew Oswald and the editor Alan Manning and two referees. Alex Bryson thanks the ESRC for financial support (grant number RES-000-23-1603).
} 
This paper draws attention to a trend hitherto unnoticed, namely an increase in the size of the union membership wage premium in the UK public sector relative to the private sector. This finding is surprising because it implies that union bargaining power has held up reasonably well in the public sector, despite the fact that union density has declined at a similar rate to the decline in the private sector. It is also surprising because it seems implausible that there should be a substantial union wage premium in the public sector. Unlike in the private sector, the majority of public sector workers have pay set directly through collective bargaining or through Pay Review Bodies, whether or not they are union members. In seeking to account for these findings we explore a number of possible explanations.

We establish the link between union membership and collective bargaining coverage in the two sectors to see whether membership is more closely aligned with coverage in the public sector, perhaps resulting in a higher premium. We consider the possibility that some workers misclassify themselves as public sector workers when, in fact, they work in public sector workplaces under contract to private sector firms. If, as is likely, these 'misclassified' workers are more likely to be union non-members, this could account for a seemingly large public sector union membership wage premium. We assess how much of the gap in the membership premium between the two sectors is accounted for by worker heterogeneity which is usually unobserved in more parsimonious wage models.

We focus on two potential sources of unobserved heterogeneity which may bias the union wage premium estimates. The first is the nature of employment contracts and, in particular, permanent versus temporary contracts and full-time versus part-time working. It is conceivable that, since such a high percentage of public sector workers are union members, those that are not may be the most marginalized of workers in the sector - in contrast to the private sector where most workers are non-members. Non-membership may therefore proxy particularly poor working conditions in the public sector relative to the private sector. The second potential source of heterogeneity is the occupational distribution of workers by union status in the two sectors. We also use linked employeremployee data to address the possibility that the union membership premium in both sectors reflects unobserved workplace heterogeneity, rather than unionization per se. This investigation is prompted by the possibility that in the more highly unionized public sector, non-members may be disproportionately located in workplaces with lower union density and/or poorer terms and conditions, relative to their member counterparts, leading to a larger union membership wage gap than in the public sector.

We find the public and private sector membership wage premia persist having controlled for a full range of individual, job and workplace characteristics. Using data from the Labour Force Survey the gap between the membership premium in the public and private sectors closes with the addition of occupational controls. However, using data from the Workplace Employment Relations Survey 2004, the public sector union membership wage premium remains roughly twice the size of the private sector membership premium having accounted for workplace fixed effects, workers' occupations, their job characteristics, qualifications and worker demographics. Furthermore, the membership wage premium among workers covered by collective bargaining is only apparent in the 
public sector. We argue that these findings are worthy of further investigation since they have public policy implications for wage setting.

\section{Union Effects on Wages}

A primary goal of trade unions is to maintain and improve workers' terms and conditions, particularly workers who are members of the union, through collective bargaining with employers. Whether unions are successful depends, in large part, on their bargaining strength - which is based on their ability to restrict the supply of labour to the employer and the ability of employers to concede above-market wages (Freeman and Medoff, 1984; Blanchflower et al, 1990).

Unions' bargaining strength is enhanced by the percentage of all workers they represent and leads to a higher union wage premium (Freeman and Medoff, 1981; Lewis, 1986; Stewart, 1987; Forth and Millward, 2002). Where the vast majority of workers in a given industry are covered by collective bargaining union-negotiated wages have less impact on the employer's cost competitiveness than in instances in which competing employers have ready access to non-union labour. This is because above-market wage costs are faced by all competitors. Unions' success in raising wages is further enhanced if the price elasticity of demand for products or services in the industry is low, as might be the case where there is a monopoly or oligopolistic production, since employers are able to meet additional costs from above-normal profits or pass the additional costs onto consumers without undue fear of being undercut by other producers.

It is normally assumed that the mechanism by which unions create a union wage premium is through their direct impact on covered workers' wages through pay bargaining. However, there are a variety of ways in which a union-non-union wage differential can emerge. The first is unions' ability to limit downward wage flexibility in times of hardship relative to their uncovered counterparts: this shows up as a countercyclical rise in the premium (Blanchflower and Bryson, 2004a). A second is the possibility that union-induced wage hikes limit worker entry to the union sector, or result in job cuts that increase the supply of labour to the non-union sector, thus lowering wages relative to those paid in the covered sector. A third union wage effect, which may compress the union wage differential, is the 'threat' effect whereby non-union employers raise their wages to avoid the threat of unionization (Rosen, 1969; Freeman and Medoff, 1981; Farber, 2003). Unions may also have more indirect effects on wages. For instance, their 'voice' face lengthens job tenure, which is itself often correlated with higher wages, and alters the incentives employers and workers face when investing in their human capital. ${ }^{1}$

\section{The Union Wage Premium in the Public Sector}

The empirical literature on the union wage premium is one of the largest in labour economics and dates back to the seminal work of H. Gregg Lewis (1963). Economists' interest lies in the fact that wages set through collective bargaining may differ from the

1 Unions are also known to have large effects on fringe benefits and non-wage labour costs, as well as methods of payment. 
wages that employers may have set unilaterally. The literature indicates that, in general, union bargaining results in wages above the market rate and in a wage distribution that is more compressed than the distribution in the non-union sector (Freeman and Medoff, 1984; Blanchflower and Bryson, 2003). Traditionally the literature has focused on the private sector where unions' ability to appropriate rents can have direct implications for employers' competitiveness, their demand for labour, and price setting. Less attention has been paid to the size of the union wage premium in the public sector. This is because it is much more heavily unionized and it is often assumed that most workers will receive collectively bargained rates of pay, even if they are not themselves union members, through practices which extend collectively bargained rates, either as a matter of public policy or because the practice is regarded as commensurate with the public sector's role as a 'good employer' and a 'fair employer'. Furthermore, although union pay setting in the public sector has implications for public-private sector wage differentials, the absence of a financial maximand in the public sector has meant that it has a less direct bearing on employment growth and workplace survival in the public sector.

However, these circumstances have begun to change in the last two decades in a way that makes estimation of the public sector union wage premium of more interest and concern. First, the Workplace Industrial Relations Surveys show that public sector union density dropped in the second half of the 1980s and continued to fall into the 1990s (Table 1). The Labour Force Survey shows union density in the public sector has continued to fall since then, albeit at a slow rate (Table 2).

Second, pay determination in the public sector began to change. As Table 1 shows, the percentage of workplaces recognizing unions for pay determination fell from 99 percent in 1984 to 87 percent in 1990, a figure that has remained stable since. By 2004, 17 percent of public sector workplaces with 10 or more employees had no workers covered by collective bargaining, and a further 27 percent used other methods of pay setting for at least some of their employees (Kersley et al., 2006: 183-184). In one-third (32 percent) of public sector workplaces some employees' pay was set through Pay Review Bodies, and in 28 percent some employees' pay was set unilaterally by management (Kersley et al., op., cit.).

The third change has been the increase in competition among providers of public services. Some public services are now offered by private sector organizations, while many non-core activities supporting public services have been contracted out. Table 3 shows that sub-contracting rose substantially, in both the public and private sectors, since 1990. In the public sector this is apparent in six of the seven activities for which we have data. These changes have been occasioned by increased concerns regarding the size of the public sector pay bill and the cost efficiency of private versus public providers of services. Managers in the public sector are thus focused on cost efficiencies and there is generally more careful scrutiny of pay setting in the public sector than there was a few decades ago. 
Together, these changes in the public sector mean it is both more meaningful to estimate the union membership premium in the public sector than it used to be and the findings are perhaps of more policy-relevance than they once were.

\section{Identifying the Union Wage Premium}

The discussion above highlights the potential causal effect that unions may have on wages, both in the covered and uncovered sectors. However, there are serious difficulties in being able to isolate the causal impact of unions on wages because of the difficulties identifying the counterfactual, that is, what wages would look like in the absence of unions. The presence of unions in the economy can change the level and distribution of wages generally. In theory, these general equilibrium effects may both raise and reduce the level of aggregate wages in the economy (Farber, 2001). Since it is not possible to observe wages in the absence of unions the effect is very difficult to estimate. Instead, estimates of union wage effects assume a partial equilibrium framework. ${ }^{2}$ The unionnon-union wage differential (the wage gap), defined as

$$
\Delta=\frac{W_{u}-W_{n}}{W_{n}}
$$

is estimable because we observe the wages of members $\left(W_{u}\right)$ and non-members $\left(W_{n}\right)$. Provided differentials are small, this expression is usefully approximated by

$$
\Delta \approx \Delta_{u}-\Delta_{n},
$$

which says that the measured union wage gap is approximately equal to the difference in the proportional effects of unions on the union and non-union wage. The union wage gap in equation (1) can be usefully approximated by the difference in log wages, implying that

$$
\Delta \approx \ln \left(W_{u}\right)-\ln \left(W_{n}\right) .
$$

The union wage gap may reflect the direct effect of unions on the wages of unionized workers, and the offsetting effects on non-union workers.

The fact that unionisation is not randomly assigned means that it is very difficult to isolate the true causal impact of unions on wages. Biased estimates are likely to occur because factors unobserved by the analyst which affect wages may also affect worker and employer selection into the covered sector. Thus union status is endogenous with respect to wages. Selection into union status is likely to be a function of both worker and employer choices (Abowd and Farber, 1982). The wage standardisation policy of trades unions is well-known to workers and will be most appealing to those workers with low underlying earnings potential since they have most to gain through unionization. However, not all workers who desire union employment can find union jobs (Bryson and Freeman, 2006). This affords employers the opportunity to pick workers from the queue and since, unlike the analyst, they are able to observe the quality of workers in the queue, they will choose the best in the queue. As Farber (2001: 19) notes, the two selection

\footnotetext{
2 Where union wage setting affects a large percentage of the working population and union effects are sizeable general equilibrium effects are likely to be substantial. For an example of such a study see Sanner (2003).
} 
processes appear to have offsetting effects on the estimated wage gap, with the worker selection implying negative bias and the employer selection implying positive bias. However, the effect of double selection on ordinary least squares (OLS) estimates of the union wage gap is uncertain a priori since it depends on the relative size of the two biases.

This is not the only selection issue that may affect estimates of union wage effects. A second is unions' choice of employer for organizing, a choice that is likely to be influenced by the cost of organising, the benefits of organising - and, in particular, the availability of surplus profits - and working conditions conducive to worker desire for union solutions (such as low or unfair pay). Third, employers may have some choice as to whether they are in the covered or uncovered sector, or the type of collective agreement they adhere to.

For these reasons analysts have experimented with alternative methods in identifying the effect of unions on wages. Ever since H. Gregg Lewis's pioneering research (1963; 1986) in which he argued that Ordinary Least Squares (OLS) estimates were the least biased estimator of union wage effects, most analysts have contented themselves with estimates of a union membership wage premium based on OLS. However, OLS only returns an unbiased union impact where all factors influencing both unionisation and wages are accounted for. This 'selection on observables' assumption, known as the conditional independence assumption in the treatment literature, requires a very rich set of covariates.

However, even with rich cross-sectional data there are likely to be factors determining both unionisation and wages which are not observable to the researcher. These might include worker motivation which may lead workers to become union members - if, for instance, they wish to have a voice in workplace organisation or job design - as well as affecting their wages (for instance, through the effort they devote to their job). This has led researchers to explore methods of tackling selection on unobservables. With crosssectional data this entails the simultaneous estimation of union status and earnings to account for the simultaneity. The approach relies on assumptions regarding functional form and the use of instrumental variables which affect the probability of union status but do not have a direct bearing on wages. These instruments are hard to find and it is generally difficult to design them into surveys. Furthermore, they often lead to unstable estimates which are frequently much larger than those obtained through other methods (Lewis, 1986). ${ }^{3}$

Our data do not contain suitable instruments. We therefore adopt an OLS approach to estimation in this paper. We do not seek to control for the potential endogeneity of union membership. Rather, we adopt the standard approach to estimation of the union-non-

3 Reasons why IV impacts differ so much have recently been discussed in Heckman et al. (2006). They show IV estimates vary where returns to treatment are heterogeneous and individuals select into treatment with partial knowledge of idiosyncratic returns. 
union wage gap using individual-level data and estimating by OLS. That is, at the individual worker level at time $t$,

$\ln \mathrm{W}_{\mathrm{t}}=\mathrm{a}_{\mathrm{t}}+\mathrm{a}_{\mathrm{xt}} \mathrm{X}_{\mathrm{t}}+\delta_{\mathrm{t}} \mathrm{U}_{\mathrm{t}}+\mathrm{e}^{\mathrm{f}}+\varepsilon_{\mathrm{t}}$,

where subscript it indexes individuals over time, $X_{t}$ is a vector of worker, job and workplace characteristics, $U_{t}$ is a dummy variable indicating union membership, and $e^{f}$ is the fixed (time invariant part) of the error term and $\varepsilon_{t}$ is the remaining random component. (The t subscript is omitted from the WERS analyses since we use a single cross-section). The parameter $\delta$ represents the average proportional difference in wages between union and non-union workers adjusted for worker and workplace characteristics, and it is the regression-adjusted analogue of $\Delta$.

\section{Data and Estimation}

We use the Labour Force Surveys from 1993-2006 to estimate the union wage premium over time and the Workplace Employment Relations Survey 2004 (WERS) to estimate the premium with linked employer-employee data.

The Labour Force Survey (LFS) is a quarterly sample survey of households living at private addresses. Its purpose is to provide information on the UK labour market that can then be used to develop, manage, evaluate and report on labour market policies. The survey seeks information on respondents' personal circumstances and their labour market status during a specific reference period, normally a period of one week or four weeks (depending on the topic) immediately prior to the interview. Each quarter's LFS sample of 53,000 UK households is made up of five waves, each of approximately 11,000 private households. Each wave is interviewed in five successive quarters, such that in any one quarter, one wave will be receiving their first interview, one wave their second, and so on, with one wave receiving their fifth and final interview. Thus there is an $80 \%$ overlap in the samples for each successive quarter.

Average gross hourly pay data for employees and those on a government scheme have been available from winter 1992/93 onwards. ${ }^{4}$ Data on union status is only available in Autumn quarters so our dataset consists solely of Autumn quarters from 1993-2006. The

\footnotetext{
4 The quarterly LFS launched in 1992 in GB and in 1994 in NI operated on a seasonal quarter basis: March-May (Spring), June-August (Summer), September-November (Autumn) and December-February (Winter). The reasons for this were

(i) Many activities associated with the labour market occur seasonally and follow the pattern of the school year. This was more the case when the LFS first started at which point more young people left school at Easter than in the summer.

(ii) Easter can cause difficulty as it varies in timing between March and April - so ensuring that Easter is always covered by the same quarterly survey period avoids this problem.

In May 2006 the LFS moved to calendar quarters (CQ's) which means the micro data is no longer available on a seasonal basis (spring - winter). The main reason ONS is moving to CQ's for the LFS is that it is an EU requirement has a target structure for the survey with all Member States providing data on a CQ.
} 
LFS has the advantage that it is publicly available and has a large number of control variables. ${ }^{5}$

WERS is a cross-sectional survey of workplace managers responsible for employment relations linked to employees in working in those workplaces. ${ }^{6}$ The 2004 survey is confined to workplaces with at least 5 employees. Both the manager and employee survey have high response rates. The dependent variable is hourly wages derived from banded wage data and continuous hours' data. We take the mid-point in the wage bands and divide by hours, estimating regressions with a robust estimator. ${ }^{7}$

In addition to the high quality of the data, WERS has a number of advantages in estimating the union wage premium. First, it contains rich workplace covariates that are usually lacking in the individual or household-level data used in many studies. Recent empirical research indicates that the paucity of employer controls tends to result in an upward bias in union wage effects. This is because unionised workplaces tend to be better paying than non-union workplaces for reasons that are not directly attributable to union membership (Blanchflower and Bryson, 2004b). ${ }^{8}$ The linkage of employees to employer data is thus likely to reduce the bias in estimating union wage effects. Second, WERS contains multiple observations on employees per workplace, thus allowing us to estimate workplace fixed effects models which compare the wages of union members and non-members within the same workplace. Third, WERS identifies which occupations within the workplace have their pay set by collective bargaining. Since the employee data contain occupational classifications we are able to identify which employees are covered by collective bargaining. Assuming that workplace managers responsible for employment relations know more about methods of pay determination than their employees, these coverage data are likely to be less prone to measurement error than surveys relying on employee responses. Where covered and uncovered workers are present in the same workplace multiple employee observations linked to workplace data make it is possible to estimate the within-workplace effect of coverage. However, when interpreting such estimates one needs to bear in mind the 'spillover' effect of coverage in pay setting for non-covered workers. Forth and Millward (2002) present evidence of this spillover

\footnotetext{
5 This is in contrast with the Annual Survey of Hours and Earnings (ASHE), formerly known as the New Earnings Survey (NES) which is a sample 1\% of workers and is based on employer records. ASHE does not contain crucial details, for example, of the workers' education level, race or union membership. Also, since 2000 the micro-data have not been publicly available. For a discussion of the differences in the earnings data in the LFS and ASHE see Ormerod and Ritchie, (2007).

6 For full details of the survey see Kersley et al. (2006).

7 The top wage band is top-coded using a value of 1.5 times the lower band. We tested the sensitivity of our results to the use of interval regression techniques. They make no substantive difference to the results. We have also tested the sensitivity of our results to the use of survey weights. The unweighted estimates produce slightly larger estimates of the membership premium but also make no substantial difference to our overall results.

8 Other studies (eg. Farber, 2001) have shown that biases in OLS cross-sectional estimates due to unobserved heterogeneity may both upwardly or downwardly bias the 'true' impact.
} 
effect. Booth and Bryan (2004) use multiple worker observations per workplace to estimate the union membership wage premium among covered workers.

A fourth reason why WERS is a valuable data source for investigating the union membership wage premium is that it helps us overcome an important measurement issue that might result in an upward bias of the union wage premium in the public sector. The measurement problem arises from the potential for private sector employees working in public sector establishments to misclassify themselves as public sector employees. Hicks et al. (2005) point to a discrepancy of more than 1.2 million workers between estimates of public sector employment derived from the Labour Force Survey, based on households, and the numbers derived from administrative and survey data from public sector organizations. ${ }^{9}$ In 2004Q1 there were 5,746,000 public sector employees in the UK using data from public sector organizations compared with 6,907,000 using data from the LFS (Hicks et al, 2005, Table 8). They argue that the numbers in the LFS are considerably higher because

"respondents can unknowingly report themselves in the public sector when really they are in the private sector according to National Account definitions......Employees working for agencies and or contractors can also classify themselves as working in the public sector in the LFS when, in reality, because their employer is a private sector organization they should be allocated to the private sector according to the National Accounts definitions". (Hicks et al, 2005, pp.9-10)”

WERS does not face this problem since the public sector status of employees is ascribed to them by their employer. Employers identify which sector they are in and then provide a listing of their employees from which employee respondents are drawn. Thus, in the case of WERS, an employee working on a public sector site for a private sector contractor would be correctly classified as a private sector employee.

There is some dispute in the literature as to what is deemed the appropriate set of conditioning variables in identifying the union membership wage premium. In the first place, some argue that the membership premium is not relevant: what matters is coverage by collective bargaining since this is what determines pay levels. In practice, many data sets do not contain a coverage variable or, if they do, there are concerns about measurement error, leading analysts to prefer the membership indicator. In our analysis we focus on the membership premium but test its sensitivity to the inclusion and exclusion of a coverage dummy. We also consider the membership premium among covered employees. Second, there is some discussion as to whether to incorporate occupational codes since one may argue that they simply represent segments of the wage distribution. In our case, it is important to test the sensitivity of our results to the inclusion of occupational dummies to establish whether any difference in the size of the membership premium between the public and private sectors is simply due to different occupational distributions of members and non-members in the two sectors. Third,

9 Downloadable at www.statistics.gov.uk 
analysts vary in their choice of job-related conditioning variables: some argue that job tenure and other variables are themselves a function of unionization and, as such, remove some of the union-based differences in wages across members and non-members. Again, in our case, we test the sensitivity of results to more and less parsimonious models to establish the degree to which any membership premium can be explained by these jobrelated differences across members and non-members.

\section{Results}

Over the last twenty years or so there have been declines in union membership across most OECD countries (Blanchflower, 2007). The decline in unionization rate that has occurred in the UK does not appear to have been accompanied by a large fall in compensation of union workers relative to non-union workers. Table 2 shows some decline in the raw union membership wage premium in both the public and private sectors. However, research tracking the regression-adjusted premium over a longer timeframe suggests that some of this recent decline may be counter-cyclical rather than secular (Blanchflower, 1999; Blanchflower and Bryson, 2003, 2004a).

Table 4 reports estimates of the union membership wage premium for the UK using the LFS over the period 1993-2006. Panel A shows the raw premium in the public and private sectors for all workers and for men and women separately. The raw premium is $26 \log$ points or $29.7 \%$ (calculated as the antilog of .2602, minus one). The raw premium is lower in the second half of the period in the private sector than in the first half of the period for both men and women. The public sector raw union membership wage premium is higher than in the private sector throughout the period, the gap being much more pronounced in the case of women. In contrast to the private sector, the raw premium is roughly constant over time in the public sector and even rises a little for men.

Panel B shows regression-adjusted estimates of the union membership wage premium controlling for variables identified in the notes to the table. These controls account for a sizeable part of the raw membership premium in both the private and public sectors but a significant premium remains for all twenty-seven estimates presented. In all cases the public sector union wage gap is higher than in the private sector.

Table 5 Panel A shows the distribution of union members and non-members in the public and private sectors across dimensions of their jobs. In the public sector Professional occupations and Associate Professional/Technical workers make up 57 percent of union members, compared to only 33 percent of non-members. In the private sector the figures are 21 percent and 18 percent respectively. Thus union members are heavily concentrated in professional and technical occupations in the public sector, unlike their non-member counterparts. This is not the case in the private sector where union members are more evenly distributed across occupations, although they are 'overrepresented' among Process Plant and Machine Operatives. One might therefore expect union members to be relatively highly paid among public sector workers simply because of their occupational status.

Panel B in Table 5 shows union density within occupations across the public and private sectors. Public sector workers are more heavily unionized than private sector workers in 
all occupations. However, the rank order of union density by occupation differs in the two sectors. In the public sector, the occupation with the highest union density is Professionals, followed by Associate Professionals/Technical workers. So, not only do they account for a high percentage of all unionized workers in the public sector, these occupations also have very high union density and, as such, might be expected to have substantial bargaining power. In the private sector the occupation with the highest union density and thus the potential for high bargaining power is Process, Plant and Machine Operatives.

To account for these differences in the occupational profiles of workers in the public and private sectors Panel $\mathrm{C}$ of Table 4 adds over three hundred and fifty detailed three digit occupational controls to the LFS specifications discussed above. Comparing results in Panel C with those in Panel B, the addition of detailed occupational controls results in a larger union membership wage premium in the private sector. The separate analyses by sex reveal that this result is driven by what happens to the male union membership wage premium. Among men, the addition of occupational controls doubles the premium in the private sector and lowers it slightly among women. In the public sector, on the other hand, the introduction of occupational controls lowers the membership premium for men and women, the effect being most pronounced for women. As a result, the union membership wage premium for men is lower in the public sector than it is in the private sector, whereas among women the membership premium is roughly comparable across the two sectors.

We explore the link between the union membership wage premium in the two sectors and employees' occupational status by estimating the membership premium within each major occupational classification. Table 6 does this using pooled LFS data for the period 2001-2006. The membership premium is positive and statistically significant in both sectors for all occupational groups with one exception, namely managers and senior officials in the private sector where the premium is weakly negative. In general, it seems that the membership wage premium for higher occupations is larger in the public sector than in the private sector, whereas the premium for lower occupations is larger in the private sector. The membership premium is larger in the public sector than the private sector for Managers and senior officials, Professional occupations and Associate Professionals and Technical Staff. The premium is roughly the same among Administrative and Secretarial Staff. However, the union membership premium among both Personal Service occupations and Elementary occupations is much larger in the private sector than it is in the public sector.

The other point emerging from Panel A in Table 5 is that the gap in job quality between union members and non-members, as measured by being on fixed-term contracts and in part-time jobs is larger in the public sector than the private sector. That is to say, union non-members are more likely to be on poorer contracts than union members in the public sector than they are in the private sector, confirming our conjecture mentioned in the introduction. Both these factors may reduce non-members' wages relative to members' wages and, since the discrepancies are greater in the public than the private sector, they may increase the wages of members relative to non-members to a greater degree in the 
public than the private sector. Of course, these job features are endogenous with respect to union membership. Nevertheless, we decided to test the sensitivity of our results to the inclusion of these controls, together with job tenure, which is lower for non-members than members in both sectors. We re-estimated the three equations in row 1 of part B of Table 4 for 1993-2006 for the whole economy and then for the private and public sectors simply adding controls for years of job tenure with the current employer and the nature of the employment contract distinguishing between seasonal, casual, fixed-term and 'other' non-permanent contracts as well as between full-time and part-time employees. The results were as follows:

\begin{tabular}{llr} 
& \multicolumn{1}{c}{ Table 4 estimates } & \multicolumn{1}{c}{ New estimates } \\
All & $.0939(\mathrm{n}=185,778)$ & $.0485(\mathrm{n}=185,623)$ \\
Private sector & $.0662(\mathrm{n}=132,315)$ & $.0226(\mathrm{n}=132,204$ \\
Public sector & $.1280(\mathrm{n}=53,463)$ & $.0824(\mathrm{n}=53,419)$
\end{tabular}

Including these controls lowers the estimated union membership premium in both sectors, the effect being particularly pronounced in the private sector. Thus, contrary to expectations, rather than reducing the gap in the union membership wage premium between the two sectors, introducing controls for job quality further accentuates the gap.

As noted earlier, the way employees are sampled in WERS means we are unlikely to encounter the misclassification problem which might plague the LFS. Furthermore, the coverage variable is also less likely to be prone to error since it is collected from workplace managers of employment relations rather than relying on employees' selfreporting.

Table 7 presents OLS estimates of the union membership wage premium using WERS. The raw premium is substantially larger in the public sector than the private sector (columns 1 and 2). ${ }^{10}$ The introduction of controls for demographic characteristics, qualifications, three digit occupational classification, region and workplace characteristics reduces the premium in both sectors very substantially and goes a long way towards closing the gap in the membership premium between the two sectors (columns 3 and 4). However, the membership premium in the public sector remains a little higher than the premium in the private sector - in contrast to the findings in Panel C of Table 4. The introduction of potentially endogenous job controls reduces the membership premium still further in both sectors, but it remains statistically significant in both sectors and is a little larger in the public sector (columns 5 and 6).

WERS 2004 confirms our expectation that coverage and membership are more highly correlated in the public sector than the private sector. In the public sector, 63 percent of union members belong to an occupation which their workplace manager says has pay set

\footnotetext{
10 The public sector raw union membership premium in WERS is similar to that for the LFS in 2004 but the private sector premium is a little bigger in WERS than it is in the LFS (see Table 2).
} 
through collective bargaining, compared to 51 percent in the private sector. However, the addition of a coverage dummy has little impact on the pattern of these results. ${ }^{11}$

We tackle the issue of potential unobserved workplace heterogeneity by running estimates of the union membership wage premium with workplace fixed effects using a robust estimator (Table 8). Workplace heterogeneity plays an important role in reducing the size of the union membership wage premium in the private sector - cutting it by around a half (compare models (1) in Tables 7 and 8). However, the premium actually rises in the public sector when comparing the wages of members versus non-members in the same workplace (compare models (2) in Tables 7 and 8). The introduction of demographic controls and 3-digit occupational classification reduces the size of the estimated premium in both sectors, particularly in the public sector. Nevertheless, the membership premium remains larger in the public sector than in the private sector (models (3) and (4)). The inclusion of potentially endogenous job controls in models (5) and (6) reduces the premium still further but it remains statistically significant in both sectors and is roughly twice as large in the public sector as it is in the private sector. These within-workplace estimations of the union membership wage premium which also include detailed occupation controls are strong evidence of a union effect on wage setting in both sectors, and of a larger effect in the public sector.

We further attempted to determine whether there was a membership premium among those workers who, according to their workplace manager, had their pay set via collective bargaining. We estimated both OLS and fixed effects models using the same controls as in the estimates presented above. The raw membership premium among covered workers is roughly twice as large in the public sector as it is in the private sector, but is only marginally larger once regression-adjusted (Table 9 rows 1 and 2). Within workplace estimates of the membership premium among covered workers were estimated using fixed effects estimation (rows 4-6). With workplace fixed effects there appears to be no statistically significant union membership wage premium among covered workers in the private sector, confirming Booth and Bryan's (2004) previous analyses using WERS 1998. However, in contrast, members continue to be paid a premium over their nonmember counterparts in the same workplaces, even when controlling for detailed occupational classification. That premium is in the order of around 5 percent (and 4 percent when potentially endogenous job controls are included in row 6). ${ }^{12}$

11 These estimates are available from the authors on request.

12 We also examined data on wage changes from the longitudinal element of the LFS. We pooled together data from 1997-2004 and 2006 for individuals aged 16-64; no data are available for 2005 because of the switch to calendar years. Approximately half of the individuals in the Quarterly LFS files attrited for one reason or another. In total that gave us 36,113 observations of which $3.6 \%$ of workers switched from union in year 1 to nonunion in year 2 while $4.0 \%$ switched from non-union in year 1 to union in year 2 . We were unable to find any statistically significant results using these data (results not reported). The reason for this finding is likely in part due to measurement error as well as to attrition bias. It is also likely driven by the fact that there are only small numbers of workers changing their union status; the decline in density has largely been driven by old (union) firms dying and new (non-union) firms being born. At the same time there has been a rise in the proportion of individuals who have never been union members even in unionized firms (Bryson and Gomez, 2005). 


\section{Conclusions}

Research on trade unions' wage effects is largely confined to the private sector. However, the growth of the non-union public sector has made it more meaningful to consider union effects in that sector, while increasing competition in the provision of public services has meant that union effects are attracting greater policy interest. The paper is motivated by two initial observations. First, the raw membership premium continues to be large in both sectors, although it has declined a little. Second, the raw membership wage premium is much larger in the public sector than it is in the private sector. We investigate potential reasons for this sectoral difference in the membership wage premium using the Labour Force Survey and the Workplace Employment Relations Survey. Our starting point is the observation that there are substantial differences in the distribution of union members in the public and private sectors according to job characteristics and job quality. Aspects of this worker and workplace heterogeneity are not usually captured in standard wage regression models, and so may account for the differences in the premium across the two sectors.

Using the Labour Force Survey we show just how heterogeneous the union wage premium is across workers. In particular, it differs systematically in the two sectors across occupations: in higher occupations the membership premium is larger in the public sector than in the private sector whereas, in lower occupations, it is larger in the private sector than it is in the public sector. If all occupations are pooled in models which contain detailed occupational controls there is no differential across sectors in the membership premium among women, and the male membership premium is actually lower in the public sector than it is in the private sector. On the other hand, contrary to expectations, controlling for potentially endogenous job quality variables actually accentuates the gap between the membership premium in the public and private sectors.

Using the Workplace Employment Relations Survey confirms that the gap between the membership wage premium in the public and private sectors closes when controlling for a more extensive set of variables. However, in contrast to the LFS, the membership premium remains a little larger in the public sector than in the private sector, whatever one controls for. This is even the case within workplaces. The public sector union membership wage premium remains roughly twice the size of the private sector membership premium having accounted for workplace fixed effects, workers' occupations, their job characteristics, qualifications and worker demographics. Furthermore, the membership wage premium among workers covered by collective bargaining is only apparent in the public sector.

We conclude that the membership wage premium in the public sector is not merely an artifact of private sector workers misclassifying themselves as working in the public sector. Rather, the union membership wage premium in the public sector is very robust to controlling for a wide range of detailed workplace, job and demographic controls. The same is true for the private sector membership wage premium. Thus, despite the weakening of unions in the UK over the last quarter century, unions continue to play an important role in wage formation. For the first time, we have shown that this is also the 
case in the public sector, even within workplaces and controlling for detailed occupational classification. Given the importance government attaches to pay equity in general, and to the role of the public sector in achieving equitable pay outcomes, these findings are worthy of further investigation. 
Table 1. Unionization in the Public and Private Sectors, 1980-2004

\begin{tabular}{|l|c|c|c|c|c|}
\hline & 1980 & 1984 & 1990 & 1998 & 2004 \\
\hline \% workplaces with recognized union & & & & & \\
Public & 94 & 99 & 87 & 87 & 87 \\
Private & 50 & 48 & 38 & 24 & 22 \\
\hline \% workplaces with members but no union recognition & & & & & \\
Public & 5 & 1 & 12 & 11 & 10 \\
Private & 11 & 10 & 11 & 12 & 15 \\
\hline Union density, workplace-weighted & & & & & \\
Public & 85 & 80 & 73 & 61 & 64 \\
Private & 41 & 32 & 25 & 13 & 13 \\
\hline Union density, employee-weighted & & & & & \\
Public & 84 & 81 & 72 & 58 & 58 \\
Private & 57 & 45 & 36 & 25 & 20 \\
\hline
\end{tabular}

Notes:

(1) Source: Workplace Industrial Relations Surveys, 1980-2004. Authors' calculations

(2) All workplaces with 25+ employees 
Table 2. Labour Force Survey Union Density and Raw Trade Union Membership Wage Premium, UK employees, 1995-2006

\begin{tabular}{|l|c|c|c|c|}
\hline & \multicolumn{2}{|c|}{ Union Membership Density (\%) } & \multicolumn{2}{c|}{$\begin{array}{c}\text { Raw Membership Wage } \\
\text { Premium (\%) }\end{array}$} \\
\hline & Private & Public & Private & Public \\
\hline 1995 & 21.6 & 61.5 & 13.2 & 26.9 \\
\hline 1996 & 20.9 & 61.1 & 13.0 & 26.7 \\
\hline 1997 & 20.2 & 61.3 & 12.1 & 23.3 \\
\hline 1998 & 19.5 & 61.0 & 9.7 & 22.4 \\
\hline 1999 & 19.3 & 59.9 & 8.9 & 27.4 \\
\hline 2000 & 18.8 & 60.2 & 7.5 & 27.5 \\
\hline 2001 & 18.6 & 59.3 & 6.3 & 29.9 \\
\hline 2002 & 18.2 & 59.7 & 6.1 & 28.9 \\
\hline 2003 & 18.2 & 59.1 & 8.3 & 26.5 \\
\hline 2004 & 17.2 & 58.8 & 6.4 & 23.4 \\
\hline 2005 & 17.2 & 58.6 & 8.1 & 22.3 \\
\hline 2006 & 16.6 & 58.8 & 9.1 & 22.5 \\
\hline
\end{tabular}

Source: H. Grainger and M. Crowther (2007), ‘Trade Union Membership 2006’, Department of Trade and Industry, London

Table 3. Percentage of Workplaces Subcontracting Services, 1990-2004

\begin{tabular}{|l|l|l|l|l|l|l|}
\hline & \multicolumn{3}{|c|}{ Private sector } & \multicolumn{3}{c|}{ Public sector } \\
\hline & 1990 & 1998 & 2004 & 1990 & 1998 & 2004 \\
\hline Cleaning & 55 & 71 & 72 & 56 & 61 & 66 \\
\hline Security & 33 & 46 & 45 & 13 & 29 & 31 \\
\hline Catering & 20 & 22 & 19 & 36 & 52 & 50 \\
\hline Building maintenance & 66 & 71 & 72 & 54 & 67 & 73 \\
\hline Printing/photocopying & 29 & 25 & 18 & 10 & 14 & 15 \\
\hline Payroll & 13 & 17 & 25 & 5 & 25 & 41 \\
\hline Transport documents/goods & 47 & 52 & 43 & 21 & 29 & 23 \\
\hline
\end{tabular}

Source: Workplace Employment Relations Surveys, 1990-2004.

Workplaces with 25+ employees. Authors' calculations 
Table 4. Union Wage Differentials, 1993-2006, LFS.

\begin{tabular}{|c|c|c|c|}
\hline \multirow{2}{*}{\multicolumn{2}{|c|}{ A) No controls }} & \multirow[t]{2}{*}{ Private } & \multirow[t]{2}{*}{ Public } \\
\hline & & & \\
\hline 1993-2006 & $.2602(n=196,069)$ & $.1864(n=139,374)$ & $.2677(n=56,249)$ \\
\hline 1993-1999 & $.2870(\mathrm{n}=89,790)$ & $.2190(\mathrm{n}=64,176)$ & $.2665(n=25,365)$ \\
\hline 2000-2006 & $.2368(n=106,279)$ & $.1559(n=75,198)$ & $.2687(n=30,884)$ \\
\hline \multicolumn{4}{|l|}{ Men } \\
\hline 1993-2006 & $.1661(n=95,388)$ & $.1116(n=75,394)$ & $.1366(n=19,768)$ \\
\hline 1993-1999 & $.1869(n=44,077)$ & $.1397(n=34,585)$ & $.1275(n=9,363)$ \\
\hline 2000-2006 & $.1471(n=51,311)$ & $.0853(n=40,809)$ & $.1445(n=10,405)$ \\
\hline \multicolumn{4}{|l|}{ Women } \\
\hline 1993-2006 & $.3402(n=100,681)$ & $.1955(n=63,980)$ & $.3140(n=36,481)$ \\
\hline 1993-1999 & $.3656(n=45,713)$ & $.2189(n=29,591)$ & $3166(n=16,002)$ \\
\hline 2000-2006 & $.3190(n=54,968)$ & $.1739(n=34,389)$ & $.3120(n=20,479)$ \\
\hline \multicolumn{4}{|c|}{ B) With controls } \\
\hline 1993-2006 & $.0939(n=185,778)$ & $.0662(n=132,315)$ & $.1280(n=53,463)$ \\
\hline 1993-1999 & $.1020(n=80,287)$ & $.0809(n=57,606)$ & $.1294(n=22,681)$ \\
\hline 2000-2006 & $.0868(n=105,491)$ & $.0521(n=74,709)$ & $.1271(n=30,782)$ \\
\hline \multicolumn{4}{|l|}{ Men } \\
\hline 1993-2006 & $.0443(n=90,077)$ & $.0407(n=71,391)$ & $.0568(n=18,686)$ \\
\hline 1993-1999 & $.0477(n=39,272)$ & $.0486(n=30,943)$ & $.0505(\mathrm{n}=8,329)$ \\
\hline 2000-2006 & $.0397(n=50,805)$ & $.0312(n=40,448)$ & $.0611(n=10,357)$ \\
\hline \multicolumn{4}{|l|}{ Women } \\
\hline 1993-2006 & $.1374(n=95,701)$ & $.1005(n=60,924)$ & $.1538(n=34,777)$ \\
\hline 1993-1999 & $.1491(n=41,015)$ & $.1195(n=26,663)$ & $.1599(n=14,352)$ \\
\hline 2000-2006 & $.1290(n=54,686)$ & $.0842(n=34,261)$ & $.1498(n=20,425)$ \\
\hline \multicolumn{4}{|c|}{ C) Plus narrow occupation controls } \\
\hline 1993-2000 & $.0990(96,546)$ & $.1072(69,221)$ & $.0806(27,325)$ \\
\hline 2001-2006 & $.0789(89,183)$ & $.0823(63,059)$ & $.0681(26,124)$ \\
\hline \multicolumn{4}{|l|}{ Men } \\
\hline 1993-2000 & $.0787(47,226)$ & $.0920(37,262)$ & $.0424(9,964)$ \\
\hline 2001-2006 & $.0714(42,821)$ & $.0814(34,106)$ & $.0444(8,715)$ \\
\hline \multicolumn{4}{|l|}{ Women } \\
\hline 1993-2000 & $.1122(49,320)$ & $.1124(31,959)$ & $.0973(17,361)$ \\
\hline 2001-2006 & $.0826(46,362)$ & $.0759(28,953)$ & $.0788(17,409)$ \\
\hline
\end{tabular}

Source: Labor Force Surveys, Autumn quarters. Notes: equations include the following controls - year dummies, age and its square, gender, 4 race dummies, 47 highest qualifications dummies, 61 industry dummies and 21 region of work dummies. Dependent variable is the log of hourly earnings - gross weekly pay divided by basic usual hours. In part A year dummies are included. In part C there are 370 and 353 occupation dummies respectively for years 1993-2000 and 2001-2006. 


\begin{tabular}{lcccr}
$\begin{array}{l}\text { Table 5A: Distribution of Union and Non-Union Workers in the Public and Private } \\
\text { Sectors (\%) }\end{array}$ & \multicolumn{3}{c}{ Public } & \multicolumn{2}{c}{ Private } \\
& Non-union & Union & Non-union & Union \\
Managers and senior officials & $8 \%$ & $6 \%$ & $18 \%$ & $11 \%$ \\
Professional occupations & $16 \%$ & $30 \%$ & $8 \%$ & $9 \%$ \\
Associate professional/technical & $17 \%$ & $27 \%$ & $10 \%$ & $12 \%$ \\
Administrative and secretarial & $24 \%$ & $14 \%$ & $13 \%$ & $9 \%$ \\
Skilled trade occupations & $2 \%$ & $2 \%$ & $10 \%$ & $15 \%$ \\
Personal service occupations & $17 \%$ & $12 \%$ & $6 \%$ & $4 \%$ \\
Sales and customer service occupations & $1 \%$ & $1 \%$ & $12 \%$ & $8 \%$ \\
Process plant and machine operatives & $1 \%$ & $1 \%$ & $8 \%$ & $19 \%$ \\
Elementary occupations & $13 \%$ & $7 \%$ & $14 \%$ & $12 \%$
\end{tabular}

\begin{tabular}{lrrrr} 
& \multicolumn{2}{c}{ Public sector } & \multicolumn{2}{c}{ Private sector } \\
& Non-Union & Union & Non-Union & Union \\
\% all workers & 11 & 17 & 58 & 14 \\
$\%$ female & 67 & 61 & 42 & 32 \\
Male & & & & \\
Non-white & 33 & 39 & 53 & 66 \\
London \& South East & 6 & 5 & 5 & 5 \\
Job Tenure & 34 & 27 & 35 & 25 \\
Ever do overtime & 7 & 11 & 5 & 11 \\
Fulltime & 38 & 56 & 47 & 62 \\
Permanent Job & 58 & 78 & 73 & 86 \\
$\quad$ Seasonal & 85 & 95 & 94 & 97 \\
Fixed contract & $*$ & $*$ & 1 & $*$ \\
Temp agency & 10 & 4 & 2 & 2 \\
Casual work & 1 & $*$ & 1 & $*$ \\
Other temporary & 2 & $*$ & 2 & $*$ \\
Basic Work hours & 1 & 1 & 1 & 36 \\
$<=10$ employees at workplace & 10 & 34 & 34 & 9 \\
>=50 employees at workplace & 63 & 68 & 27 & 71 \\
Degree or higher degree & 23 & 33 & 43 & 11 \\
Tenure 1 year or less & 31 & 12 & 15 & 46 \\
Tenure >=10 years & 26 & 50 & 19 & \\
& & & 38 &
\end{tabular}


Table 5B: Union Density by Occupation in Public and Private Sectors (\%)

$\begin{array}{lcc} & \text { Public } & \text { Private } \\ \text { Managers and senior officials } & 52.9 & 12.2 \\ \text { Professional occupations } & 72.2 & 21.0 \\ \text { Associate professional and technical } & 69.2 & 21.2 \\ \text { Administrative and secretarial } & 44.7 & 13.0 \\ \text { Skilled trades occupations } & 62.9 & 25.0 \\ \text { Personal service occupations } & 49.9 & 12.7 \\ \text { Sales and customer service occupation } & 48.2 & 13.0 \\ \text { Process, plant and machine operatives } & 64.2 & 34.8 \\ \text { Elementary occupations } & 42.2 & 16.0\end{array}$

Source: Labour Force Surveys Autumn quarters (September, October and November), 2001-2006 plus August 2003 and December 2006 (n=196,366).

Table 6. Union Membership Wage Premium by Occupation, 2001-2006

Wage gap T-statistic N

Public sector

Managers and senior officials $\quad .0420$

Professional occupations $\quad .0728$

2.39

1,885

Associate professional and technical

.0690

6.29

6,293

Administrative and secretarial

.0723

6.79

5,915

Personal service occupations

.1113

7.45

4,794

Elementary occupations

.0753

9.17

3,632

4.89

2,531

Private sector

Managers and senior officials

$-.0247$

1.65

10,802

.0319

1.92

4,917

Associate professional and technical

.0456

3.36

6,578

Administrative and secretarial

.0701

5.11

8,110

Skilled trades

.1303

11.36

6,878

Personal service occupations

.1965

9.16

3,544

.0381

3.14

7,259

Process, plant \& machine operatives

.1568

16.68

6,317

Elementary occupations

.1321

11.85

8,654

Source: Labor Force Surveys, Autumn quarters. Notes: equations include the following controls - year dummies, age and its square, gender, 4 race dummies, 47 highest qualifications dummies, 61 industry dummies and 21 region of work dummies. Dependent variable is the log of hourly earnings - gross weekly pay divided by basic usual hours. 
Table 7. OLS Estimates of the Union Membership Wage Premium, WERS 2004

\begin{tabular}{|l|c|c|c|c|c|c|}
\hline & $(1)$ & $(2)$ & $(3)$ & $(4)$ & $(5)$ & $(6)$ \\
\hline & Private & Public & Private & Public & Private & Public \\
\hline Union member & 0.120 & 0.202 & 0.051 & 0.064 & 0.035 & 0.052 \\
\hline & $(10.72)$ & $(15.73)$ & $(5.83)$ & $(6.28)$ & $(3.91)$ & $(5.01)$ \\
\hline Constant & 2.113 & 2.115 & 2.351 & 2.516 & 2.414 & 2.654 \\
\hline & $(383.28)$ & $(206.75)$ & $(31.76)$ & $(13.95)$ & $(32.16)$ & $(14.67)$ \\
\hline Observations & 12,818 & 5,934 & 12,818 & 5,934 & 12,818 & 5,934 \\
\hline R-squared & 0.01 & 0.04 & 0.53 & 0.52 & 0.55 & 0.53 \\
\hline
\end{tabular}

Notes:

(1) T-statistics in parentheses.

(2) Models (1) and (2): raw premium without controls

(3) Models (3) and (4): includes following controls - male, age (9 dummies), academic qualifications (8 dummies), vocational qualifications (3 dummies), health problem, white British, household composition (4 dummies); 3-digit SOC (81 dummies); industry (12 dummies); region (10 dummies); establishment size (7 dummies); single workplace organization; workplace age (4 dummies); foreign owned (private sector only). (4) Models (5) and (6): (3)/(4) plus the following controls: permanent contract; full-time contract; workplace tenure (5 dummies); training days (4 dummies); gender segregation of the job at the workplace (6 dummies)

Table 8: Estimates of the Union Membership Wage Premium with Workplace Fixed Effects

\begin{tabular}{|l|l|l|l|l|l|l|}
\hline & $(1)$ & $(2)$ & $(3)$ & $(4)$ & $(5)$ & $(6)$ \\
\hline & Private & Public & Private & Public & Private & Public \\
\hline Union member & 0.054 & 0.237 & 0.037 & 0.060 & 0.024 & 0.049 \\
\hline & $(4.54)$ & $(18.10)$ & $(3.61)$ & $(5.64)$ & $(2.35)$ & $(4.59)$ \\
\hline Constant & 2.129 & 2.093 & 2.389 & 2.519 & 2.523 & 2.701 \\
\hline & $(451.44)$ & $(205.62)$ & $(40.06)$ & $(24.04)$ & $(38.40)$ & $(24.48)$ \\
\hline Observations & 12818 & 5934 & 12818 & 5934 & 12818 & 5934 \\
\hline R-squared & 0.00 & 0.06 & 0.32 & 0.45 & 0.34 & 0.47 \\
\hline
\end{tabular}

Notes:

(1): T-statistics in parentheses.

(2) Private sector models contain fixed effects for 1237 workplaces. Public sector models contain fixed effects for 484 workplaces

(3): Models (1) and (2): raw premium without controls

(4): Models (3) and (4) contain following controls: male, age (9 dummies), academic qualifications (8 dummies), vocational qualifications (3 dummies), health problem, white British, household composition (4 dummies); 3-digit SOC (81 dummies)

(5): Models (5) and (6): (3)/(4) plus the following controls: permanent contract; full-time contract; workplace tenure (5 dummies); training days (4 dummies); gender segregation of the job at the workplace (6 dummies) 
Table 9: Union Membership Wage Premium Among Covered Workers

\begin{tabular}{|l|c|c|}
\hline & Private & Public \\
\hline OLS & & \\
\hline 1. No controls & $0.083(4.70)$ & $0.151(9.51)$ \\
\hline 2. + demographics, 3-digit SOC, workplace controls & $0.053(3.71)$ & $0.062(5.07)$ \\
\hline 3. As 2 + job controls & $0.041(2.86)$ & $0.046(3.64)$ \\
\hline Workplace fixed effects & & \\
\hline 4. No controls & $0.030(1.75)$ & $0.157(9.74)$ \\
\hline 5. + demographics, 3-digit SOC & $0.015(0.97)$ & $0.054(4.08)$ \\
\hline 6. As 5 + job controls & $0.008(0.50)$ & $0.037(2.77)$ \\
\hline
\end{tabular}

Notes:

(1) T-statistics in parentheses

(2) Model coefficients with t-statistics in parentheses.

(3) Demographic controls: male, age (9 dummies), academic qualifications (8 dummies), vocational qualifications (3 dummies), health problem, white British, household composition (4 dummies).

(4) Workplace controls: industry (12 dummies); region (10 dummies); establishment size (7 dummies); single workplace organization; workplace age (4 dummies); foreign owned (private sector only).

(5) Job controls: permanent contract; full-time contract; workplace tenure (5 dummies); training days (4 dummies); gender segregation of the job at the workplace (6 dummies).

(6) Fixed effects models contain 303 workplaces in the private sector and 384 in the public sector. 


\section{References}

Abowd, J. and Farber, H. (1982), 'Job queues and the union status of workers', Industrial and Labor Relations Review, 36, pp. 354-367

Blanchflower, D.G. (2007), 'International patterns of union membership', British Journal of Industrial Relations, March, Volume 45, Number 1, pp. 1-28.

Blanchflower, D.G. and A. Bryson (2003), 'Changes over time in union relative wage effects in the UK and the US revisited,' in J.T. Addison and C. Schnabel, eds. International handbook of trade unions. Cheltenham, UK: Edward Elgar, pp. 197-245.

Blanchflower, D.G. and A. Bryson (2004a), 'What effect do unions have on wages now and would Freeman and Medoff be surprised?', Journal of Labor Research, XXV(3), Summer, pp. 383-414.

Blanchflower, D.G. and Bryson, A. (2004b) 'Union relative wage effects in the United States and the United Kingdom', Proceedings of the $56^{\text {th }}$ Annual Meeting of the Industrial Relations Research Association, pp. 133-140.

Blanchflower, D.G., A.J. Oswald and M.D. Garrett, 'Insider power in wage determination', Economica, 57, pp. 143-170.

Booth, A.L. and M.L. Bryan (2004), 'The union membership wage-premium puzzle: is there a free rider problem?', Industrial and Labor Relations Review, 57(3), April, pp. 402421.

Bryson, A, (2003), 'Employee desire for unionization in Britain and its implications for union organizing', Working Paper, Policy Studies Institute, London.

Bryson, A. and Freeman, R. (2006), 'Worker needs and voice in the US and the UK', NBER Working Paper \#12310, Cambridge, Mass.

Bryson, A. and R. Gomez (2005), 'Why have workers stopped joining unions? Accounting for the rise in never-membership in Britain', British Journal of Industrial Relations, March ,Volume 43, Number 1, pp. 67-92.

Farber, H. (2003), 'Nonunion wage rates and the threat of unionization', NBER Working Paper \#9705.

Farber, H. (2001), 'Notes on the economics of labor unions', Princeton University Industrial Relations Section Working Paper \#452

Forth, John and Neil Millward (2002), 'Union effects on pay levels in Britain', Labour Economics, 9, pp. 547-561.

Freeman, R.B. and J. Medoff (1984), What do unions do?, Basic Books. 
Grainger, H. and Crowther, M. (2007), 'Trade union membership, 2006’, Department of Trade and Industry, London.

Heckman, J. J. Urzua, S. and Vytlacil, E. (2006) 'Understanding instrumental variables in models with essential heterogeneity', paper to the Comparative Analysis of Enterprise Data Conference, Chicago.

Hicks, S, C. Lindsay, D. Livesey, N. Barford, and R. Williams (2005) 'Public sector employment', Labour Market Division and Employment, Earnings and Productivity Division, Office for National Statistics, UK.

Kersley, B., Alpin, C., Forth, J., Bryson, A., Bewley, H., Dix, G. and Oxenbridge, S. (2006), Inside the workplace: findings from the 2004 Workplace Employment Relations Survey, London: Routledge.

Lewis, H. G. (1963), Unionism and relative wages in the United States: an empirical inquiry, University of Chicago Press, Chicago, IL, USA.

Lewis, H. G. (1986), Union relative wage effects: a survey, University of Chicago Press, Chicago, IL, USA.

Ormerod, C. and F. Ritchie, (2007), 'Linking ASHE and LFS: can the main earnings sources be reconciled?’, Economic \& Labour Market Review, Vol. 1 No 3,March, Office for National Statistics

Rosen, S. (1969) 'Trade union power, threat effects and the extent of organization', Review of Economic Studies, 36, pp. 185-196

Stewart, M. B. (1987), 'Collective bargaining arrangements, closed shops and relative pay’, Economic Journal, 97 (385), pp. 140-156. 